17. Frankenburg W.K., Dodds I.B. Denver Developmental Screening Test // Pediatry. 1997. V. 71. № 2.

18. Leiter R.G. Leiter International Performance Scale // Instraction Manual Cat. №37041M. USA, 1979.

19. Linder T.W. Transdisciplinary Play-Based Assessment. A Functional Approach to Working with Yong Children. Baltimor, 1999.

20. Rossetti L.M. Infant-toddler assessment. An interdisciplinary approach Austin : PRO-ED, 1990.

21. Strauss R.S. Effects of the intrauterine environment on childhood growth // Brit. Med. Bull. 1997. № 1.

УДК 376.1

Л.М. Лапиина

Нейрофизиологический аспект работы олигофренопедагога с семьей обучающегося на дому

DOI 10.20323/978-5-00089-474-3-2021-54-58

Аннотащия. В статье обобщен и описан собственный опыт взаимодействия олигофренопедагога с учениками, имеющими выраженные степени умственной отсталости и обучающимися на дому. В современных условиях такие школьники эффективно обучаемы только в условиях взаимодействия педагога и семьи с учетом нейрофизиологического подхода.

Ключевые слова: взаимодействие, семья, школьники с тяжелыми и множественными нарушениями развития, обучение на дому, нейрофизиологический аспект.

\title{
L.M. Lapshina
}

Neurophysiological aspect of the work of an oligophrenopedagogue with a schoolchild's family at home

Abstract. The article summarizes and describes the personal experience of interaction between an oligophrenopedagogue and students with pronounced degrees of mental retardation and home-schooled students. In modern conditions, such students are effectively taught only in the conditions of interaction between the teacher and the family, taking into account the neurophysiological approach.

(C) Лапшина Л.М., 2021 
Keywords: interaction, family, schoolchildren with severe mental retardation, home-based learning, neurophysiological aspect.

Дети с выраженными нарушениями интеллекта (далее - ВНИ) - это особая категория детей с ограниченными возможностями здоровья, образование которых в современной России, по большому счету, только начинается [Лапшина, Левченко, 2018]. Такие дети в силу специфики структуры дефекта [Лапшина, 2020] чаще всего получают образование на дому, поэтому взаимодействие олигофренопедагога и семьи ребенка с ВНИ - это обязательное условие эффективной помощи такому ребенку в освоении определенного стандарта знаний [Федеральный закон..., 2014].

Анализ современной научной литературы по проблеме исследования [Коробинцева, 2018а; Коробинцева, 2018б] и собственный опыт обучения таких учащихся [Лапшина, 2020] позволяет утверждать, что во взаимодействии олигофренопедагога образовательной организации и семьи, воспитывающей ребенка с ВНИ, сегодня ведущим является нейрофизиологический аспект.

Работа с ребенком начинается с диагностического обследования - это первое по организации сопровождения, направление. Именно с определения реального актуального уровня развития ребенка начинается работа с ним. Основная цель - конкретизация структуры дефекта. Организуется обследование как через использование стандартизированных диагностических методик [Лапшина, 2020], так и в ходе регулярного педагогического наблюдения за учеником в различных учебных, бытовых и игровых ситуациях. Чем тщательное проведено первое диагностическое обследование, тем более полным содержанием наполняется структура дефекта и диагноз, представленный в заключении протокола психолого-медикопедагогической комиссии. Результатом такой диагностики становится клинико-психолого-педагогическая характеристика ребенка [Хайкина, Лапшина, 2016]. Именно конкретизация клиническогонейрофизиологического аспекта в ходе первичной диагностики зоны актуального развития ребенка позволяет определить и зону ближайшего развития.

Структура дефекта детей с ВНИ имеет, как правило, проявление нарушения и на соматовегетативном уровне, которое проявляется в различных хронических заболеваниях внутренних органов и систем. Среди наиболее часто встречающихся следует отметить вегетососуди- 
стую дистонию, мигрени, наличие в структуре электроэнцефалограммы эпи-активности, поэтому при диагностике образовательных возможностей ребенка с ВНИ необходимо учитывать и объяснять родителям это условие. Понимание значимости соматовегетативного статуса лежит в основе использование родителями при работе с здоровьесберегающих технологий. Особенно это важно при формировании у обучающегося с ВНИ речевых форм активности - объективно сложных для обучающихся данного контингента [Коробинцева, 2018a].

Еще одним направлением взаимодействия семьи и педагога при сопровождении ребенка с тяжелыми множественными нарушениями развития является определение образовательного потенциала ребенка, выбор и индивидуализация учебной программы. Именно результаты диагностического обследования, соматовегетативного статус качественно и количественно характеризуют тот внутренне-психологический потенциал, который определен структурой дефекта, который реально есть у ребенка и который педагог может не только реализовывать в процессе занятий, но и обязан учитывать, определяя цель и задачи обучения конкретного ученика.

Ведение учебных занятий - основное по значимости направление психолого-педагогического сопровождения ребенка с ВНИ. Именно в рамках учебных занятий происходит накопление знаний и коррекция нарушенного развития ребенка. При обучении на дому занятия максимально индивидуализируются по форме, структуре, количеству уроков в течение учебного дня. Работа, начатая на занятиях олигофренопедагогом, продолжается родителями при выполнении домашнего задания и на занятиях, организуемых при этом.

Оказание дополнительных коррекционно-образовательных услуг - еще одно направление, реализация которого опирается на знании и глубоком понимании нейрофизиологического статуса [Лапшина, Левченко, 2018]. Как правило, учитель-олигофренопедагог, осуществляющий организацию образовательного процесса на дому, это единственный представитель образовательного учреждения, посещающий семью. Учитывая сложность структуры дефекта ребенка с ВНИ, учитель комплексно выполняет функцию не только учителя и дефектолога [Лапшина, Левченко, 2018], но и логопеда [Коробинцева, 2018а], и специального психолога [Лапшина, 2020], а часто и инструк- 
тора по физической культуре при выполнении физкультминуток, комплекса психогимнастики и оздоровительных пятиминуток [Хайкина, Лапшина, 2016].

Привлечение родителей к реализации образовательной программы - еще одно обязательное направление в обучении ребенка с ВНИ на дому [Лапшина, 2018]. Согласно нормативам организации образовательного процесса на дому, олигофренопедагогу отводится для посещения обучающегося 8-10 часов в неделю. Все остальное время образовательный процесс реализуют, организуют и контролируют родители. Их вклад в развитие ребенка - решающий. Однако для того чтобы этот процесс был максимально эффективным, родители должны знать нейрофизиологический статус; компетентно прокомментировать его - это задача олигофренопедагога [Коробинцева, 2018a].

Школьники с ВНИ - это достаточно новый контингент обучающихся современной отечественной системы образования, поэтому образовательный процесс не имеет необходимого методического и дидактического обеспечения на государственном уровне [Лапшина, Левченко, 2018]. Изготовление индивидуальных пособий для занятий это еще одно направление взаимодействия олигофренопедагога и родителей - в рамках которого семья часто играет ведущую роль. Именно родители, знающие нейрофизиологический статус и любящие своего ребенка, способны предложить оптимальный для него вариант [Лапшина, 2018].

Таким образом, взаимодействие олигофренопедагога и семьи в психолого-педагогическом сопровождении ребенка с ВНИ на дому процесс сложный, многоаспектный, однако только реализация его по всем выше описанным направлениям с учетом нейрофизиологического статуса школьника является обязательным условием оказания такому обучающемуся образовательных услуг, определенных специализированным Федеральным государственным образовательным стандартом.

\section{Библиографический список}

1. Коробинцева М.С. Нейрофизиологические основы логопедической коррекции речевого развития младших школьников с OB3 //Адаптация биологических систем к естественным и экстремальным факторам среды: материалы VII Международной научно-практической конференции. Челябинск : ЮУрГГПУ, 2018а. С. 234-235. 
2. Коробинцева М.С. Работа учителя-логопеда общеобразовательной организации с семьей, воспитывающей ребенка с ОВ3 // Комплексный подход к сопровождению семьи: история, тенденция развития, современные технологии помощи и поддержки: материалы Международной научно-практической конференции. Челябинск : Южно-Уральский научный центр РАО, 2018б. С. 350-356.

3. Лапшина Л.М. Информационно-коммуникационные технологии в формировании образовательных компетенций у детей с ограниченными возможностями здоровья // Современные технологии социальной работы и инклюзивного образования: сборник статей IX Международной научно-практической конференции, посвященной 85-летию Южно-Уральского государственного гуманитарно-педагогического университета, 25-26 апреля 2019 г. Челябинск : ЮжноУральский научно-образовательный центр РАО, 2019. С. 29-32.

4. Лапшина Л.М. Междисциплинарный подход в сопровождении образования школьников с ОВ3// Современные методы профилактики и коррекции нарушений развития у детей: традиции и инновации: сборник материалов II Международной междисциплинарной научной конференции, 22-23 октября 2020 г. Москва : Когито-Центр Московский институт психоанализа, 2020. С. 351-354.

5. Лапшина Л.М. Разработка методического обеспечения образовательного процесса детей с выраженным нарушением интеллекта/ Л.М. Лапшина, В.А. Левченко // Комплексный подход к сопровождению семьи: история, тенденция развития, современные технологии помощи и поддержки: материалы Международной научно-практической конференции. Челябинск :Южно-Уральский научный центр PAO, 2018. C. 188.

6. Российская Федерация. Законы. Федеральный государственный образовательный стандарт образования обучающихся с умственной отсталостью (интеллектуальными нарушениями): Федеральный закон № 1599-ФЗ. Москва : Эксмо, 2014. 50 с.

7. Хайкина М.А. Изучение особенностей игровой деятельности детей старшего дошкольного возраста с ЗПР / М.А. Хайкина, Л.М. Лапшина // Современные подходы к диагностике и коррекции развития детей с ограниченными возможностями здоровья : сборник научных статей по итогам научно-исследовательской работы преподавателей, студентов и выпускников факультета инклюзивного и коррекционного образования ЮУрГГПУ за 2015-2016 учебный год. Челябинск : Цицеро, 2016. С. 153-156. 